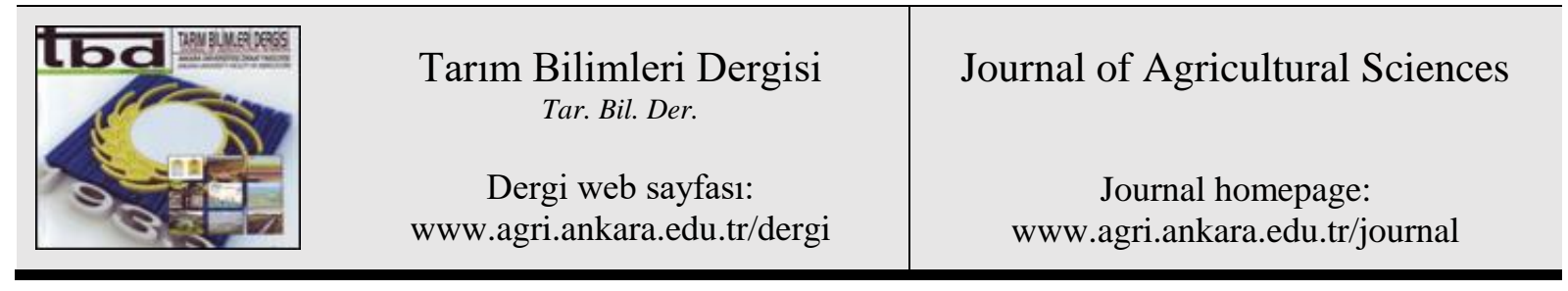

\title{
The Effect of Glyphosate on Anatomical and Physiological Features of Alfalfa Infested with Field Dodder (Cuscuta campestris Yunck.)
}

\author{
Marija SARIC-KRSMANOVIC ${ }^{\mathrm{a}}$, Ahmet ULUDAG ${ }^{\mathrm{b}}$, Dragana BOZIC ${ }^{c}$, Ljiljana RADIVOJEVIC ${ }^{\mathrm{a}}$, Jelena \\ GAJIC-UMILJENDIC ${ }^{\text {a }}$ Sava VRBNICANIN ${ }^{c}$

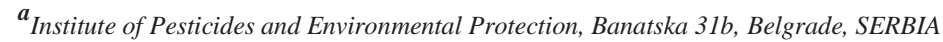 \\ ${ }^{b}$ Faculty of Agriculture, Canakkale Onsekiz Mart University, Terzioglu Campus, Canakkale, TURKEY \\ ${ }^{c}$ Faculty of Agriculture, University of Belgrade, Nemanjina 6, Belgrade, SERBIA
}

\section{ARTICLE INFO}

Research Article

Corresponding Author: Ahmet ULUDAĞ, E-mail: ahuludag@yahoo.com, Tel: +90 (537) 5781211

Received: 05 November 2018, Received in Revised Form: 21 February 2019, Accepted: 16 March 2019

\section{AUTHORS ORCID ID:}

(Marija SARIC-KRSMANOVIC: 0000-0002-7207-5736), (Ahmet ULUDAG: orcid.org/0000-0002-7137-2616), (Dragana BOZIC: 0000-0002-7355-8633), (Ljiljana RADIVOJEVIC: 0000-0002-0232-5840), (Jelena GAJIC-UMILJENDIC: 0000-0002-4129-328X), (Sava VRBNICANIN: 0000-0001-9128-9652)

\begin{abstract}
Field dodder (Cuscuta campestris Yunck.) is a very harmful parasitic weed species worldwide which infests many crops, including alfalfa as a foremost forage crop. Glyphosate has been an effective herbicide for field dodder control even though side effects occasionally occur in alfalfa plants. To find out and quantify the effects of glyphosate (288 and $360 \mathrm{~g}$ a.i. ha ${ }^{-1}$ ) on field dodder control, alfalfa forage yield, and physiological and anatomical features of alfalfa plants under controlled conditions were aims of the study. Physiologic (chlorophyll a, chlorophyll
\end{abstract}

b, total carotenoids); and anatomic parameters were measured. Leaf anatomic parameters were thicknesses of upper epidermis, palisade and spongy tissues, mesophyll and underside leaf epidermis, and diameter of bundle sheath cells. Stem anatomic parameters were thicknesses of epidermis and cortex, and diameters of stem and central cylinder (pith). Both rates of glyphosate caused recovery of the harmful effects of field dodder on alfalfa, which shows that glyphosate can control field dodder at early stages of infestation on alfalfa.

Keywords: Glyphosate; Field dodder; Leaf parameters; Pigments content; Stem parameters

\section{Introduction}

(c) Ankara Üniversitesi Ziraat Fakültesi

Alfalfa is an important forage crop in Serbia, covering approximately 200000 ha, as well as worldwide (Bokan et al 2015; Strbanovic et al 2017). Cuscuta spp. are present in anthropogenic habitats in Serbia from croplands to urban areas and have been recorded at $25 \%$ of the UTM (Universal Transverse Mercator) grid, becoming a foremost problem in alfalfa cultivation in Serbia (Vrbnicanin et al 2008). Field dodder (Cuscuta campestris) is the most common Cuscuta species globally as it has been recorded on many crop and non-crop species in South America, Europe, Asia, Africa, and Australia, as well as its native range North America (Holm et al 1997; SaricKrsmanovic et al 2015). Alfalfa losses due to field dodder have been reported to reach up to 80\% (Stojanovic \& Mijatovic 1973; Dawson 1989; Mishra 2009). Its damaging effect is more pronounced in newly established alfalfa fields (Dawson 1971).

Field dodder management requires an integrated approach, which targets from the introduction of parasite seeds to the field to avoid further dispersal of seeds by using different techniques such as preventive, cultural, biological, mechanical and chemical (Saric \& Vrbnicanin 2015). Chemical control of field dodder is a method that has been 
predominantly studied worldwide (Dawson 1966; Saric \& Vrbnicanin 2015; Boydston \& Anderson 2017). One of the herbicides that have been studied and suggested for field dodder control in alfalfa is glyphosate, phloem and xylem mobile systemic herbicide, which reaches areas of active growth through symplastic and apoplastic pathways (McAllister \& Haderlie 1985). Liu \& Fer (1990) found out that foliar applied glyphosate accumulated 26-fold more apical parts of dodder plants than hosts (Hock et al 2008). Glyphosate primarily inhibits the enzyme 5-enolpyruvylshikimate-3-phosphate synthase (EPSPS) in the shikimate pathway. Glyphosate sprayed to dodder parasitized alfalfa at different rates caused injury to death of the field dodder while there was no injury to minimal damage on alfalfa in various studies (Dawson \& Saghir 1983; Dawson 1990a; Dawson 1990b; Saric-Krsmanovic et al 2015). But, some regeneration of field dodder occurred in some cases and alfalfa plants recovered from injury in most cases (Dawson \& Saghir 1983; Dawson 1990a). In pot and field trials, glyphosate has demonstrated better results than other herbicides; however, the effectiveness of the herbicides, including glyphosate, was lower in heavily infested alfalfa fields (Saric-Krsmanovic et al 2015).

The effect of field dodder on physiologic and anatomic parameters of crops and their relation with herbicides have been reported. Field dodder reduced the contents of carotenoids, chlorophyll a, and chlorophyll b both sugar beet and alfalfa plants but herbicide treatments (imazethapyr in alfalfa and propyzamide in sugar beet) caused partial recovery of all three parameters, even with small level of stimulations 28 and/or 35 days after herbicide applications (Saric-Krsmanovic et al 2016; Saric-Krsmanovic et al 2017). Field dodder significantly decreased all measured anatomic features of leaf and petiole of sugar beet plants, compared to noninfested ones; but, propyzamide treatment caused different levels of recovery of all parameters, inferring that propyzamide could control field dodder in early infestation stages (Saric-Krsmanovic et al 2017). Anatomic parameters of alfalfa stem and leaf were also studied under field dodder infestation and imazethapyr treatment. Field dodder caused some reductions in the parameters, but they were significant from the $28^{\text {th }}$ day onwards. Imazethapyr at $100 \mathrm{~g}$ a.i. ha ${ }^{-1}$ application rate resulted in a partial recovery of the measured parameters (Saric-Krsmanovic et al 2016).

Field dodder has been considered a growing problem in alfalfa production in Serbia and other countries, which indicates a need for more extensive research aimed at finding new means of parasitic weed control. Glyphosate has been confirmed as a viable option for dodder control in alfalfa crops. The effects of field dodder infestation of alfalfa have been reported (Saric-Krsmanovic et al 2016). The aim of the present study is to find out the effects of glyphosate application on physiologic and anatomic parameters and yield of alfalfa.

\section{Material and Methods}

Pot experiments were set up in a greenhouse with $28 \pm 3{ }^{\circ} \mathrm{C}$ ambient air temperature and under natural light conditions in June 2015. Physiologic and anatomic measurements were done in the laboratory. In general, the same methods were applied as those reported by Saric-Krsmanovic et al $(2016 ; 2019)$.

\subsection{Greenhouse experiment}

Plastic pots ( $17 \mathrm{~cm}$ in diameter) were filled with a mixture of a commercial substrate (Flora Gard TKS1, Germany) and soil that collected from a field without a history of herbicide application, which was loamy in texture (sand $49.8 \%$, silt $33.4 \%$, and clay $16.8 \%$ ), medium calcareous, weakly alkaline and highly humic. Twenty plants remained in each pot after thinning. Glyphosate was applied at $288 \mathrm{~g}$ a.i. ha ${ }^{-1}\left(\mathrm{~T}_{1}\right)$ or $360 \mathrm{~g}$ a.i. ha $\mathrm{h}^{-1}\left(\mathrm{~T}_{2}\right)$ rates by a thin-layer chromatography sprayer under 1-2 bars pressure over alfalfa plants at $10-12 \mathrm{~cm}$ in height and field dodder have already attached. Two different checks were included in the experiment: alfalfa plants noninfested with field dodder $(\mathrm{N})$ and infested with field dodder (I), but neither treated with glyphosate. The experimental design was an RCBD with four replications; the experiment was repeated twice. Herbicide efficacy was assessed visually assessing field dodder plants on alfalfa by using a 0 (no damage) -100 (fully death) scale and by weighing fresh biomass of alfalfa at $0,7,14,21,28,35$ days after application (DAA).

\subsection{Physiological analysis - content of pigments}

The content of pigments was measured spectrophotometrically following to methanol extraction $0,7,14,21,28$ and 35 DAA. Leaves $(0.5 \mathrm{~g})$, which had been kept in $-20{ }^{\circ} \mathrm{C}$ until the processing were ground in a blender with 5 $\mathrm{mL}$ methanol followed by vacuum filtering and centrifuging for $10 \mathrm{~min}$ at $1500 \mathrm{rpm}$. Absorption was read at 470 $\mathrm{nm}$ for total carotenoids, at $666 \mathrm{~nm}$ for chl $a$ and $653 \mathrm{~nm}$ for chl $b$. Wellburn's formula (1994) to calculate 
chlorophyll $a$ and $b$ concentration, and Lichtenthaler \& Wellburn's formula (1983) for carotenoids were used.

Chlorophyll $a: \mathrm{ca}=15.65 \times \mathrm{A} 666-7.34 \mathrm{~A} 653$

Chlorophyll $b: \mathrm{cb}=27.05 \times \mathrm{A} 653-11.21 \mathrm{~A} 666$

Total carotenoids: $\mathrm{cx}+\mathrm{c}=(1000 \mathrm{~A} 470-2.86 \mathrm{ca}-129.2 \mathrm{cb}) / 221$

Pigment content was converted from $\mu \mathrm{g} \mathrm{mL}^{-1}$ to $\mathrm{mg} \mathrm{g}^{-1}$ using the Equation 4 .

$\mathrm{C}=\mathrm{cVR}(\mathrm{m} 1000)^{-1}$

Where; $\mathrm{C}$, pigment content $\left(\mathrm{mg} \mathrm{g}^{-1}\right)$; c, pigment content $\left(\mu \mathrm{gL}^{-1}\right)$; V, total extract volume $(\mathrm{mL}) ; \mathrm{R}$, dilution factor; $\mathrm{m}$, fresh weight of leaves $(\mathrm{g})$.

\subsection{Anatomical analysis}

Leaves and stems were sampled for light microscopy six times: 0, 7, 14, 21, 28 and 35 DAA. Samples were obtained by cutting $1-\mathrm{cm}$-long alfalfa stem parts where field dodder contacted alfalfa and collecting 10 of the first three true leaves from each level of plants, namely the lower, middle and upper. The samples were fixed in $50 \%$ ethanol solution and prepared for microscopy using paraffin wax method (Ruzin 1999). Embedded samples were then sliced into 5-15 $\mu \mathrm{m}$ thick sections on a microtome, then stained with toluidine blue, safranin and alcian blue. Stem parameters that were thickness of epidermis (TE), thickness of cortex (TC), diameter of stem (DS) and diameter of central cylinder (pith) (DCC); and leaf parameters that were thickness of upper epidermis (TUPE) and underside leaf epidermis (TUNE), thickness of palisade (TPT), spongy (TST) and mesophyll (TMT) tissues, and diameter of vascular bundle cells (DVBC) were measured as 30 replicates each. Measuring process completed using the LEICA IM 1000 software package followed to visualization by a light microscope LEICA DMLS and photographing by a digital camera LEICA DC 300.

\subsection{Statistical analysis}

The data were combined and underwent variance analysis and tested by Fisher's Least Significant Difference (LSD) test $(\mathrm{P}<0.05)$ by using Statistica 8.0. software. Principal component analysis $(\mathrm{PCA})$ was run based on combinations of four treatments by six assessment times and four parameters of stem or six parameters of leaf anatomy of alfalfa in order to define the best control treatment with precision.

\section{Results and Discussion}

\subsection{Effects of field dodder and glyphosate applications on alfalfa yield}

The impact of field dodder on alfalfa fresh weight was significant. Noninfested alfalfa plants were gaining 18.35 $\mathrm{g}$ fresh weight per pot (from $8.00 \mathrm{~g} 0$ DAA to $26.35 \mathrm{~g} 35 \mathrm{DAA}$ ) over the 35 days period, while field dodder-infested plants lost $2.70 \mathrm{~g}$ (measuring from $6.88 \mathrm{~g} 0$ DAA to $4.18 \mathrm{~g} 35 \mathrm{DAA}$ ) (Figure 1). It is an $84 \%$ fresh fodder loss, which is unacceptable to farmers. Alfalfa crop losses due to field dodder had been assessed in earlier studies at $60 \%$ in Chile, and $80 \%$ in Serbia (Stojanovic \& Mijatovic 1973; Mishra 2009). In a three-year field trial alfalfa loss due to smoothseed dodder (Cuscuta approximata) compared to uninfested alfalfa plots changed from $7 \%$ to $70 \%$ in different years (Tepe et al 2017). The growth of field dodder was faster than that of Mikania micrantha, an invasive alien plant in China, and damage caused by field dodder qualified it a biological agent to control $M$. micrantha (Deng et al 2003; Zan et al 2003; Zhang et al 2004; Li et al 2012). Similarly, field dodder was found promising in control of Ambrosia trifida, an invasive alien plant in Europe (Vrbnicanin et al 2013).

The efficacy of both rates of glyphosate was significant compared to infested herbicide-untreated alfalfa plants. Notably, the higher rate $\left(T_{2}\right)$ gave the same yield as noninfested alfalfa plants (Figure 1). Visual estimation of field dodder damage was in parallel to fresh weight data, which was over 90\% 28 DAA and beyond (Table 1). These results are consistent with earlier studies for field dodder control in various crops (Dawson 1990a, b; Hock et al 2008; Saric-Krsmanovic et al 2015). 


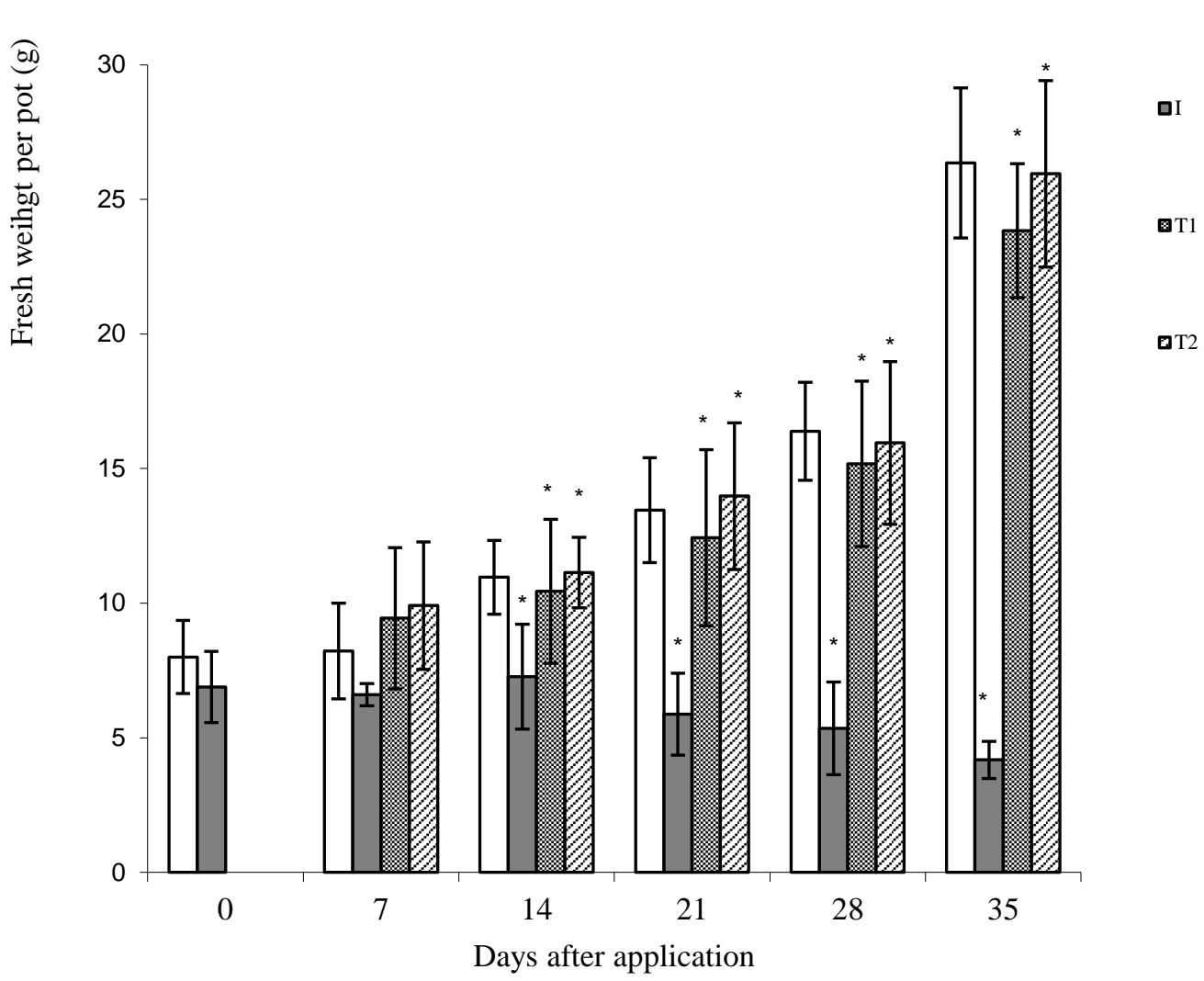

Figure 1- Effects of field dodder infestation and glyphosate treatments on alfalfa. $N$, noninfested alfalfa plants; $\mathbf{I}$, infested with field dodder but untreated with glyphosate; $T_{1}$ and $T_{2}$, treated with glyphosate $(288$ and $360 \mathrm{~g}$ a.i. ha $\left.^{-1}\right) ;$ LSD test, $\mathbf{P}<0.05$

Table 1- Visual assessment of glyphosate efficacy on field dodder plants parasitizing alfalfa

\begin{tabular}{lccccc}
\hline \multirow{2}{*}{$\begin{array}{l}\text { Treatments } \\
\left(\mathrm{g} \text { a.i. } \mathrm{ha}^{-1}\right)\end{array}$} & \multicolumn{5}{c}{ Assessments in the days after application } \\
\cline { 2 - 6 } & 7 & 14 & 21 & 28 & 35 \\
\hline Glyphosate 288 & 3.0 & 70.0 & 87.5 & 93.0 & 95.0 \\
Glyphosate 360 & 5.0 & 75.0 & 90.0 & 97.5 & 97.5 \\
\hline
\end{tabular}

\subsection{The effect of glyphosate application on physiological parameters of alfalfa}

The results of measurement of physiological parameters are presented in Figure 2. As discussed in an earlier paper, untreated alfalfa plants had reduced contents of chlorophyll $a$ up to $64 \%$, chlorophyll $b 68 \%$, and carotenoids $60 \%$ on the $35^{\text {th }}$ DAA (Saric-Krsmanovic et al 2016). Two glyphosate treatments gave very similar results, showing that herbicide-treated alfalfa plants had similar amounts of all three pigments as noninfested alfalfa plants, especially 28 DAA and beyond. Even a small amount of stimulation of carotenoids content by $\mathrm{T}_{2}$ application was measured (Figure 2). The effect of glyphosate application on dodder-infested alfalfa is consistent with the effect of imazethapyr on alfalfa and propyzamid on sugar beet (Saric-Krsmanovic et al 2016; Saric-Krsmanovic et al 2017). 


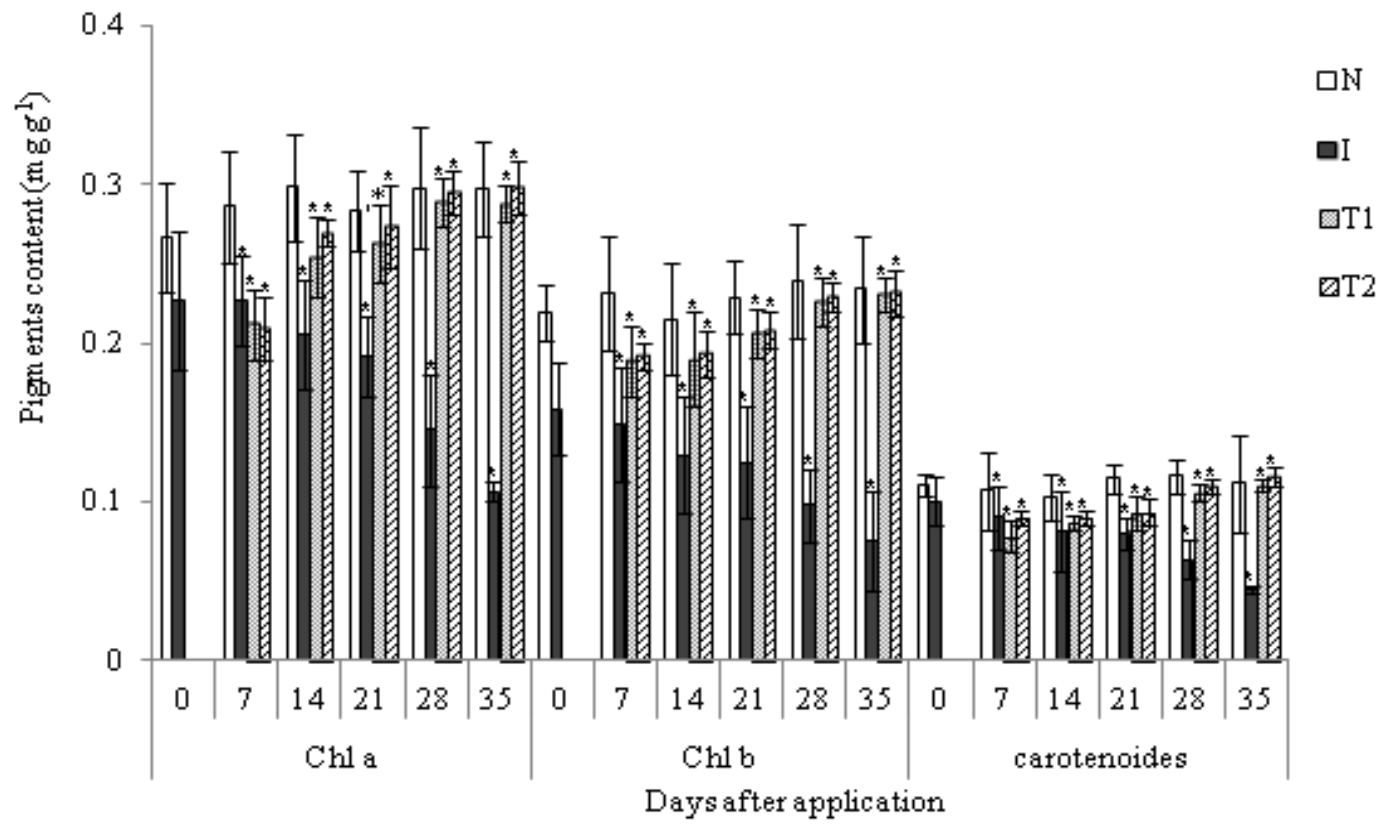

Figure 2- Contents of chlorophyll $a$ (a), chlorophyll $b$ (b) and carotenoids (c) in alfalfa plants. N, noninfested alfalfa; I, untreated with herbicide; $T_{1}$ and $T_{2}$, glyphosate-treated $\left(288 \mathrm{~g}\right.$ a.i. ha $^{-1}$ and $\left.360 \mathrm{~g} \mathrm{a.i.} \mathrm{ha}^{-1}\right)$; ${ }^{*}$ LSD test, $\mathbf{P}<\mathbf{0 . 0 5}$

\subsection{The effect of glyphosate application on anatomical parameters of alfalfa}

Data for all physiologic parameters of plants, including noninfested and untreated plants, are presented here to be able to make a meaningful explanation, although results other than glyphosate data had been reported earlier, which details can be reached at Saric-Krsmanovic et al (2016).

Leaf heights data were pooled because the leaf position did not significantly affect the parameters measured. Both glyphosate rates affected all leaf parameters to very similar degrees in an increasing manner in time. Field dodder caused reductions in the parameters, but they were significant 28 DAA and afterwards (Table 2). The highest reduction was revealed for mesophyll thickness (57\%), and the lowest for the thickness of upper epidermis $(28 \%)$. Neither rate caused a full recovery of any parameter; however, they almost reached the level of noninfested plants 35 DAA. The results were consistent with earlier studies with different herbicides applied to alfalfa and sugar beet plants (Saric-Krsmanovic et al 2016; Saric-Krsmanovic et al 2017). The PCA analysis showed that total variability among all parameters over all assessments was 78\% (PCA1 axis) and 11\% among treatments (PCA2 axis) (Figure 3). Treatments have had the most significant impact on TMT, TPT, and TUNE; but, their influences on DVBC, TST, and TUPE were smaller. Treatments $T_{1}$ and $T_{2}$ in the lower left-hand quadrant of the ordination plane had higher impact on TUNE, TUPE, and TPT than on the other parameters. The least difference was found in the leaf anatomy parameters of control alfalfa plants and those in treatments $\mathrm{T}_{1}$ and $\mathrm{T}_{2}$.

As leaf parameters, stem parameters also showed lower reductions in treated plants than in dodder-infested untreated plants, ranging from $15 \%$ to $0 \%$ (Table 3 ). Recovery from both glyphosate rates was very similar, and pronounced on the $28^{\text {th }}$ DAA and beyond. PCA1 axis confirmed a variability of $80 \%$, including all measured parameters over all assessments. Treatment variability of $13 \%$ was confirmed by PCA2 axis (Figure 4 ). Treatments had the highest impact on TE, DCC, and DS and lower effect on TC. Treatments $\mathrm{T}_{1}$ and $\mathrm{T}_{2}$ (shown in the lower left-hand quadrant of ordination plane) had the highest impact on TC and TE. Besides, the two last assessments after herbicide treatments $\left(\mathrm{T}_{1}\right.$ and $\left.\mathrm{T}_{2}\right)$ confirmed their significant impact on field dodder plants, i.e., the parameters of alfalfa stem anatomy in those treatments and the control had the least difference (Figure 4). Data showed a recovery of the infested alfalfa plants and satisfactory efficacy of the herbicide. 
The Effect of Glyphosate on Anatomical and Physiological Features of Alfalfa Infested with Field Dodder..., Saric-Krsmanovic et al.

Table 2- The effect of glyphosate treatments on alfalfa leaf parameters

\begin{tabular}{|c|c|c|c|c|c|c|c|}
\hline \multirow{2}{*}{$\begin{array}{l}\text { Parameter } \\
(\mu \mathrm{m})\end{array}$} & \multirow{2}{*}{$A p p$} & \multicolumn{6}{|c|}{ Days after application } \\
\hline & & 0 & 7 & 14 & 21 & 28 & 35 \\
\hline \multirow{4}{*}{$\begin{array}{l}\text { Thickness of } \\
\text { upper epidermis }\end{array}$} & $\mathrm{N}$ & $15.5 \pm 5.3$ & $15.6 \pm 2.8$ & $17.0 \pm 3.8$ & $17.7 \pm 4.6$ & $19.0 \pm 3.5 \mathrm{a}$ & $19.2 \pm 2.8 \mathrm{a}$ \\
\hline & I & $14.4 \pm 4.6$ & $15.3 \pm 3.7$ & $14.2 \pm 4.1$ & $14.1 \pm 2.4$ & $14.1 \pm 2.7 \mathrm{~b}$ & $13.8 \pm 4.3 \mathrm{~b}$ \\
\hline & $\mathrm{T}_{1}$ & - & $15.8 \pm 2.6$ & $15.3 \pm 4.3$ & $15.0 \pm 2.5$ & $16.2 \pm 4.2 \mathrm{c}$ & $17.2 \pm 3.5 \mathrm{ac}$ \\
\hline & $\mathrm{T}_{2}$ & - & $15.1 \pm 3.5$ & $15.5 \pm 2.4$ & $15.2 \pm 2.9$ & $16.0 \pm 3.6 \mathrm{c}$ & $18.3 \pm 4.9 \mathrm{ac}$ \\
\hline \multirow{4}{*}{$\begin{array}{l}\text { Thickness of } \\
\text { palisade tissue }\end{array}$} & $\mathrm{N}$ & $45.5 \pm 7.9$ & $54.7 \pm 13.7$ & $54.8 \pm 9.2$ & $54.9 \pm 15.5$ & $55.0 \pm 21.8 \mathrm{a}$ & $66.7 \pm 14.15 \mathrm{a}$ \\
\hline & I & $45.2 \pm 10.1$ & $44.5 \pm 9.8$ & $44.1 \pm 7.1$ & $43.0 \pm 7.9$ & $42.7 \pm 9.3 \mathrm{~b}$ & $35.0 \pm 10.8 \mathrm{~b}$ \\
\hline & $\mathrm{T}_{1}$ & - & $41.0 \pm 11.8$ & $44.9 \pm 8.7$ & $51.5 \pm 14.5$ & $55.7 \pm 10.3 \mathrm{ac}$ & $64.8 \pm 8.4 \mathrm{ac}$ \\
\hline & $\mathrm{T}_{2}$ & - & $41.0 \pm 9.2$ & $47.0 \pm 12.0$ & $48.4 \pm 15.0$ & $50.2 \pm 10.7 \mathrm{c}$ & $62.8 \pm 8.7 \mathrm{ac}$ \\
\hline \multirow{4}{*}{$\begin{array}{l}\text { Thickness of } \\
\text { spongy tissue }\end{array}$} & $\mathrm{N}$ & $47.2 \pm 10.6$ & $50.1 \pm 15.6$ & $52.5 \pm 8.9$ & $52.8 \pm 16.9$ & $54.5 \pm 11.2 \mathrm{a}$ & $66.6 \pm 15.0 \mathrm{a}$ \\
\hline & I & $46.5 \pm 10.8$ & $45.7 \pm 10.7$ & $44.7 \pm 10.3$ & $43.0 \pm 8.0$ & $41.4 \pm 16.9 b$ & $32.8 \pm 9.0 \mathrm{~b}$ \\
\hline & $\mathrm{T}_{1}$ & - & $39.4 \pm 10.5$ & $47.2 \pm 14.1$ & $48.9 \pm 9.2$ & $49.7 \pm 8.4 \mathrm{c}$ & $65.4 \pm 9.9 \mathrm{ac}$ \\
\hline & $\mathrm{T}_{2}$ & - & $42.2 \pm 7.8$ & $45.9 \pm 11.4$ & $49.0 \pm 10.9$ & $50.0 \pm 10.9 \mathrm{c}$ & $63.6 \pm 27.0 \mathrm{ac}$ \\
\hline \multirow{4}{*}{$\begin{array}{l}\text { Thickness of } \\
\text { mesophyll tissue }\end{array}$} & $\mathrm{N}$ & $14.0 \pm 4.4$ & $14.1 \pm 3.7$ & $14.8 \pm 3.4$ & $15.3 \pm 4.1$ & $15.7 \pm 3.6$ & $16.8 \pm 6.2 \mathrm{a}$ \\
\hline & I & $13.6 \pm 3.8$ & $13.5 \pm 3.1$ & $13.5 \pm 4.8$ & $13.2 \pm 4.3$ & $13.2 \pm 3.5$ & $7.2 \pm 3.6 \mathrm{~b}$ \\
\hline & $\mathrm{T}_{1}$ & - & $13.6 \pm 2.4$ & $13.3 \pm 3.1$ & $14.1 \pm 4.6$ & $14.7 \pm 3.2$ & $16.6 \pm 5.4 \mathrm{ac}$ \\
\hline & $\mathrm{T}_{2}$ & - & $12.8 \pm 2.5$ & $13.5 \pm 3.7$ & $15.1 \pm 4.4$ & $15.4 \pm 4.3$ & $15.8 \pm 5.0 \mathrm{ac}$ \\
\hline \multirow{4}{*}{$\begin{array}{l}\text { Thickness of } \\
\text { underside } \\
\text { epidermis }\end{array}$} & $\mathrm{N}$ & $93.5 \pm 22.5$ & $106.1 \pm 28.4$ & $106.8 \pm 18.8$ & $105.5 \pm 34.4$ & $111.0 \pm 22.6 \mathrm{a}$ & $112.1 \pm 28.8 \mathrm{a}$ \\
\hline & I & $91.5 \pm 15.6$ & $90.6 \pm 17.4$ & $88.8 \pm 13.9$ & $87.6 \pm 14.6$ & $85.8 \pm 24.8 \mathrm{~b}$ & $69.2 \pm 21.1 \mathrm{~b}$ \\
\hline & $\mathrm{T}_{1}$ & - & $80.2 \pm 20.9$ & $91.1 \pm 15.5$ & $94.3 \pm 26.0$ & $109.0 \pm 21.6 \mathrm{ac}$ & $111.4 \pm 14.7 \mathrm{ac}$ \\
\hline & $\mathrm{T}_{2}$ & - & $83.3 \pm 18.9$ & $93.0 \pm 21.0$ & $100.1 \pm 22.4$ & $102.2 \pm 16.0 \mathrm{c}$ & $110.9 \pm 32.6 \mathrm{ac}$ \\
\hline \multirow{4}{*}{$\begin{array}{l}\text { Diameter of } \\
\text { vascular bundles } \\
\text { cells }\end{array}$} & $\mathrm{N}$ & $12.3 \pm 4.8$ & $12.7 \pm 2.8$ & $13.1 \pm 4.3$ & $13.3 \pm 2.6$ & $13.6 \pm 4.6 \mathrm{a}$ & $13.9 \pm 4.1 \mathrm{a}$ \\
\hline & $\mathrm{I}$ & $11.6 \pm 3.1$ & $11.8 \pm 3.3$ & $10.1 \pm 2.8$ & $10.0 \pm 2.7$ & $9.3 \pm 2.7 b$ & $9.9 \pm 2.2 \mathrm{~b}$ \\
\hline & $\mathrm{T}_{1}$ & - & $9.8 \pm 1.1$ & $9.9 \pm 2.8$ & $13.1 \pm 3.9$ & $14.3 \pm 3.4 \mathrm{ac}$ & $13.4 \pm 3.3 \mathrm{ac}$ \\
\hline & $\mathrm{T}_{2}$ & - & $9.6 \pm 2.1$ & $10.9 \pm 3.4$ & $12.8 \pm 3.1$ & $13.2 \pm 2.8 \mathrm{ac}$ & $13.2 \pm 3.3 \mathrm{ac}$ \\
\hline
\end{tabular}

Means are followed by the relative standard errors and and letters which mean that the same letters within a column are not significantly different according to LSD test $(\mathrm{P}<0.05)$.

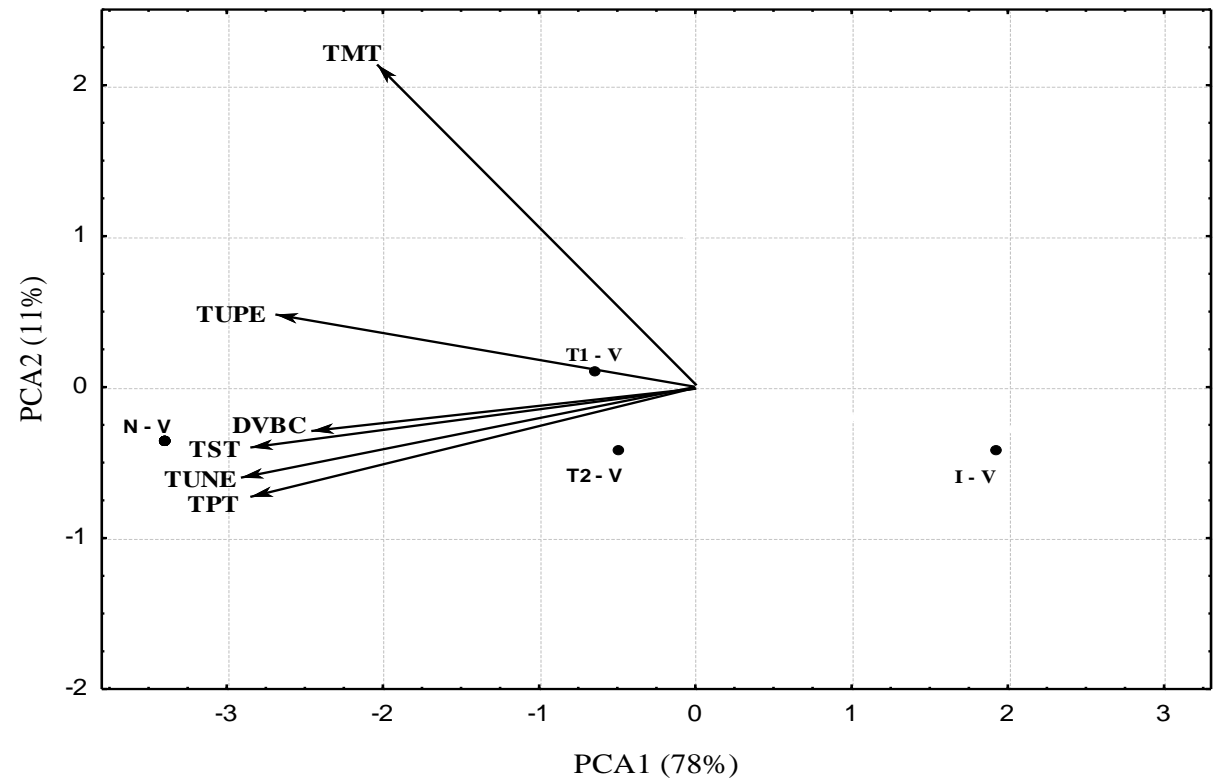

Figure 3- Principal component analysis for leaf parameters of alfalfa plants in the last assessment (35 DAA). N, noninfested by field dodder, T1 treated with glyphosate (288 g a.i. ha-1); T2 treated with glyphosate (360 g a.i. ha1); I, untreated; TUPE, thickness of upper epidermis; TUNE, thickness of underside leaf epidermis; TPT, thickness of palisade tissue; TST, thickness of spongy tissue; TMT, thickness of mesophyll tissue; DVBC, diameter of vascular bundle cells 
Table 3- The effect of glyphosate treatments on alfalfa stem parameters

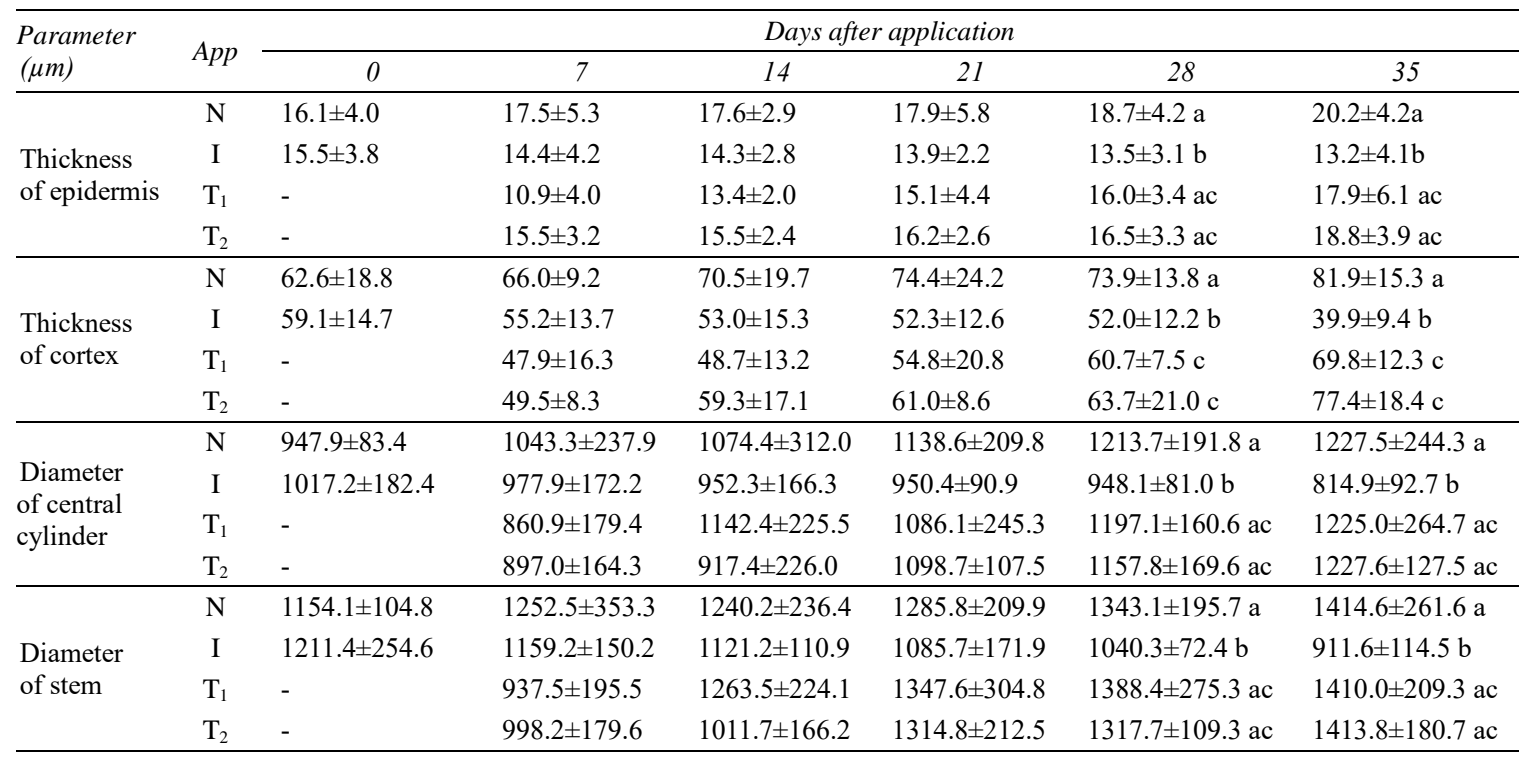

The same letters within a column are not significantly different according to LSD test $(\mathrm{P}<0.05)$.

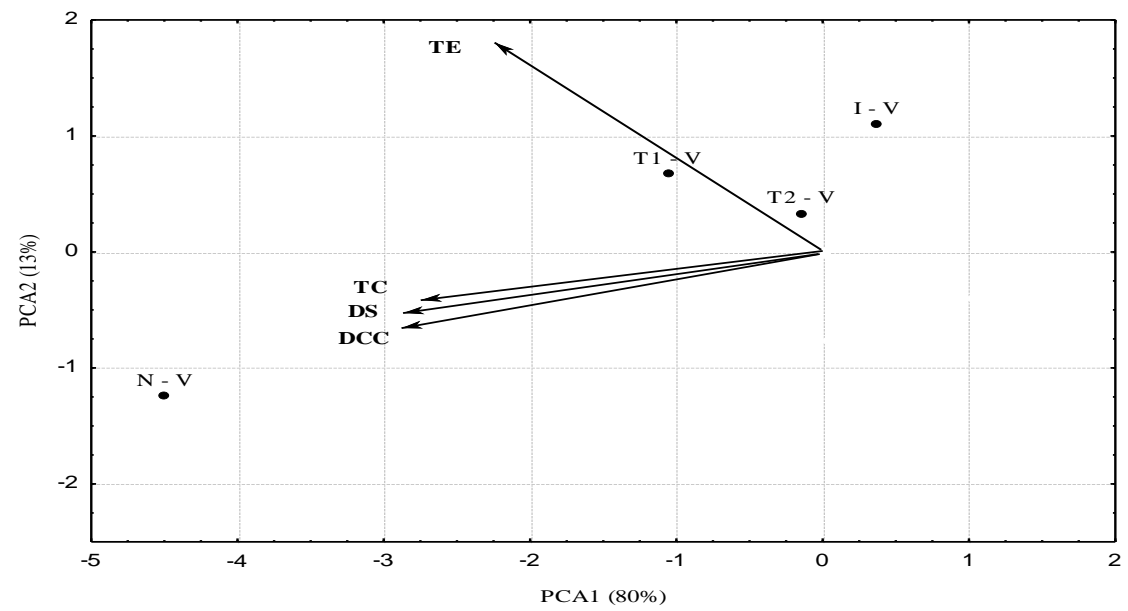

Figure 4- Principal component analysis for stem parameters of alfalfa plants in the last assessment (35 DAA). N, noninfested by field dodder, $\mathrm{T}_{1}$ treated with glyphosate $\left(288 \mathrm{~g}\right.$ a.i. $\left.\mathrm{ha}^{-1}\right)$; $\mathrm{T} 2$ treated with glyphosate $(360 \mathrm{~g}$ a.i. $\mathrm{ha}^{-1}$ ); I, untreated; thickness of epidermis (TE), thickness of cortex (TC), diameter of stem (DS) diameter of central cylinder (pith) (DCC)

\section{Conclusions}

Glyphosate rate of $288 \mathrm{~g}$ a.i. ha ${ }^{-1}$ was able to recover alfalfa fresh fodder yield, as well as physiologic and anatomic parameters from detrimental effects of field dodder, demonstrating a photosynthetic success and growth of alfalfa plants. Also, the rate of $360 \mathrm{~g}$ a.i. ha ${ }^{-1}$ did not cause any adverse effects on alfalfa. Glyphosate is an herbicide that can help to solve field dodder problem in alfalfa crops. However, it should be kept in mind that treatments in this study were carried out at a very early stage of alfalfa growth. Later applications may not be as successful as earlier ones, which many other weed control studies have already indicated.

\section{Acknowledgements}

This study was supported by the Ministry of Education, Science and Technology of the Republic of Serbia. 


\section{References}

Bokan N, Dugalic G, Katic S, Milic D, Vasiljevic S, Katanski S \& Milosevic B (2015). Yield and cost-effectiveness of alfalfa hay production as dependent on fertilization. Acta Agriculturae Serbica 20: 155-163

Boydston R A \& Anderson T L (2017). Field dodder (Cuscuta pentagona) control with flumioxazin. Weed Technology 31(6): $847-851$

Dawson J H (1966). Factors affecting dodder control with granular CIPC. Weeds 14(3): 255-259

Dawson J H (1971). Establishing alfalfa on dodder-infested soil. Weed Science 19(3): 222-225

Dawson J H (1989). Dodder (Cuscuta spp.) control in established alfalfa (Medicago sativa) with glyphosate and SC-0224. Weed Technology 3(4): 552-559

Dawson J H (1990a). Dodder (Cuscuta spp.) control with dinitroaniline herbicides in alfalfa (Medicago sativa). Weed Technology 4: 341-348

Dawson J H (1990b). Dodder (Cuscuta spp.) control in newly seeded alfalfa (Medicago sativa) with glyphosate. Weed Technology 4: 880-885

Dawson J H \& Saghir A R (1983). Herbicides applied to dodder (Cuscuta spp.) after attachment to alfalfa (Medicago sativa). Weed Science 31: 465-471

Deng X, Feng H L, Ye W H, Yang Q H, Xu K Y \& Cao H L (2003). A study on the control of exotic weed Mikania micrantha by using parasitic Cuscuta campestris. Journal of Tropical and Subtropical Botany 11: 117-122

Hock S M, Wiecko G \& Knezevic S Z (2008). Glyphosate dose affected control of field dodder (Cuscuta campestris) in the tropics. Weed Technology 22(1): 151-155

Holm L, Doll J, Holm E, Pancho J V \& Herberger J P (1997). World Weeds: Natural Histories and Distribution. John Wiley, New York. 1152 pp

Li F L, Li M G, Zan Q J, Qiang G U O, Zhang W Y, Zhi W U \& Wang Y J (2012). Effects of the residues of Cuscuta campestris and Mikania micrantha on subsequent plant germination and early growth. Journal of Integrative Agriculture 11(11): 1852-1860

Lichtenthaler H K \& Wellburn A R (1983). Determinations of total carotenoids and chlorophylls $a$ and $b$ of leaf extracts in different solvents. Biochemical Society Transactions 11(5): 591-592

Liu Z Q \& Fer A (1990). Influence d'un parasite (Cuscuta lupuliformis Krock.) sur la redistribution de deux herbicides systemiques appliques sur une legumineuse (Phaseolus aureus Roxb.). Comptes Rendus de l'Academie des Sciences-Series III-Sciences de la Vie 311: 333-339 (In French)

McAllister R S \& Haderlie L C (1985). Translocation of 14C-glyphosate and 14CO2-labeled photoassimilates in Canada thistle (Cirsium arvense). Weed Science 33: 153-159

Mishra J S (2009). Biology and management of Cuscuta species. Indian Journal of Weed Science 41: 1-11

Ruzin S E (1999). Plant Microtechnique and Microscopy. Oxford University Press, New York

Saric-Krsmanovic M \& Vrbničanin S (2015). Field dodder - How to control it? Pesticides and Phytomedicine 30(3): 137-145

Saric-Krsmanovic M, Bozic D, Malidza G, Radivojevic Lj, Gajic Umiljendic J \& Vrbničanin S (2015). Chemical control of field dodder in alfalfa. Pesticides and Phytomedicine 30(2): 107-114

Saric-Krsmanovic M, Bozic D, Radivojevic Lj, Gajic Umiljendic J \& Vrbničanin S (2016). Impact of field dodder (Cuscuta campestris Yunck.) on physiological and anatomical changes in untreated and herbicide-treated alfalfa plants. Pesticides and Phytomedicine 31(3-4): 115-120

Saric-Krsmanovic M, Bozic D, Radivojevic Lj, Gajic Umiljendic J \& Vrbničanin S (2017). Effect of Cuscuta campestris parasitism on the physiological and anatomical changes in untreated and herbicide-treated sugar beet. Journal of Environmental Science and Health Part B, 52(11): 812-816 
Saric-Krsmanovic M, Bozic D, Radivojevic L, Gajic Umiljendic J \& Vrbnicanin S (2019). Response of Alfalfa and Sugar Beet to Field Dodder (Cuscuta campestris Yunck.) Parasitism: Physiological and Anatomical Approach. Canadian Journal of Plant Science 99(2): 199-209

Stojanovic D \& Mijatovic K (1973). Distribution, biology and control of Cuscuta spp. in Yugoslavia. In: Proceedings of EWRC Symposium on Parasitic Weeds, 11-13 April, Malta pp. 269-279

Strbanovic R, Stanisavljevic R, Đukanovic L, Postic D, Markovic J, Gavrilovic V \& Dolovac N (2017). Variability and correlation of yield and forage quality in alfalfa varieties of different origin. Tarım Bilimleri Dergisi 23(1): 128-137

Tepe I, Celebi S Z, Kaya I \& Ozkan R Y (2017). Control of smoothseed alfalfa dodder (Cuscuta approximata) in alfalfa (Medicago sativa). International Journal of Agriculture and Biology 19(1): 199-203

Vrbnicanin S, Malidza G, Stefanovic L, Elezovic I, Stankovic-Kalezic R, Marisavljevic D, Radovanov-Jovanovic K, Pavlovic D \& Gavric M (2008). Distribution of some economic harmful, invasive and quarantine weeds in Serbia. II part: Spatial distribution and frequency of nine weed species. Biljni lekar 36: 408-418 (In Serbian)

Vrbnicanin S, Saric-Krsmanovic M \& Bozic D (2013). The effect od field dodder (Cuscuta campestris Yunck.) on morphological and fluorescence parameters of giant ragweed (Ambrosia trifida L.). Pesticides and Phytomedicine 28: $57-$ 62

Wellburn A R (1994). The spectral determination of chlorophylls $a$ and $b$, as well as total carotenoids, using various solvents with spectrophotometers of different resolution. Journal of Plant Physiology 144: 307-313

Zan Q J, Wang B S, Wang Y J, Zhang J L, Liao W B \& Li M G (2003). The harm caused by Mikania micrantha and its control by Cuscuta campestris. Journal of Plant Ecology 27(6): 822-828

Zhang L Y, Ye W H, Cao H L \& Feng H L (2004). Mikania micrantha H.B.K. in China-an overview. Weed Research 44: $42-49$ 